\title{
Aquatic animal resources in Prehistoric Aegean, Greece
}

Dimitra Mylona

\begin{abstract}
This paper explores the early stages in the history of fishing in the Aegean Sea in Greece, and highlights its formative phases and its specific characteristics in different points in time. This is testified by various physical remains, such as fish bones, fishing tools, and representations in art, which are gathered in the course of archaeological research. The aquatic resources in the Aegean Sea have been exploited and managed for millennia by communities that lived near the water and often made a living from it. The earliest evidence for a systematic, intensive exploitation of marine resources in the Aegean Sea dates to the Mesolithic, eleven millennia ago. In the Neolithic period, the adoption of a sedentary, agro-pastoral way of life led to a reduction in the intensity of fishing and shellfish gathering. Its importance as an economic resource remained high only in certain regions of rich, eutrophic waters. In the Bronze Age, an era of social complexity and centralized economy, the exploitation of aquatic, mostly marine, resources became a complex, multi-faceted activity which involved subsistence, industry and ideology. The range of preferred fish and invertebrate species, the fishing technology, and the processing of fish and shellfish in order to produce elaborate foods or prestige items are all traceable aspects of the complex relationship between humans and the aquatic resources throughout the prehistory of fishing and shellfish gathering in the Aegean area. The broadening of collaboration between archaeology and physical sciences offers new means to explore these issues in a more thorough and nuanced manner.
\end{abstract}

Keywords: Prehistoric fishing, Fish remains, Molluscan remains, Fish processing, Archaeology of fishing, Prehistoric aquatic resources

\section{Introduction}

The aquatic resources of the Hellenic area have been systematically exploited by coastal communities that lived by the sea, the rivers and the lakes, for a very long period of time. This interaction begun at least as early as the 11th millennium BP (Before Present) and it lead to a wide range of fishing choices and strategies. In these one can trace adaptations to the local ecosystems but also a reflection of the interests and priorities of the fishing communities involved in the exploitation of these resources. Despite the observed variability there are certain constant features which survived through the millennia to the modern era. The range of fish and shellfish, fishing tools and processing methods are some of these features. This paper provides a short review of these issues in the context of prehistoric Aegean, a period in time when the

Correspondence: dmylona@hotmail.com

Institute of Aegean Prehistory for East Crete, 59 E. Daskalaki, 74100 Rethymno, Greece basic features of the exploitation of aquatic resources were formulated.

Ancient fishing is explored through a multi-level approach by archaeology and history. The main categories of data for such an approach are the archaeological remains of aquatic resources and fishing tools as well as records in literature and representations in art. The aquatic animal remains, mostly fish bones, sea shells, crustaceans and coral skeletons, are identified using reference collections and relevant monographs; various features of these remains are recorded, particularly those that are pertinent to the animals' exploitation by humans $[1,2]$. Remains of fishing implements (most commonly their durable elements such as the bone or metal fishing hooks, the stone weights or the pumice floaters) are also recovered archaeologically [3]. Records of aquatic animals in ancient texts, along with relevant representations in art provide further evidence on fishing related matters. They also illustrate an elusive aspect of the past, 
i.e. how people thought and felt about the aquatic resources and their harvesting [4]. However, the exploitation of these resources and the particular choices made by the different communities in different times and locations, are governed not only by cultural rules and traditions but also by the restrictions imposed by the dynamics of the aquatic environments and the biology and ethology of the exploited organisms [5]. Therefore, archaeological and historical research is supplemented by a range of natural sciences, such as ichthyology, marine biology, chemistry, etc. It should be emphasized that such a combined approach, effective as it may be, does not provide a snapshot of the available aquatic resources at that period but it reflects the resources that were accessed by humans, of those elements that were used by people as food, raw material and/or symbols.

\section{Review}

\section{The abundance of marine resources in the Mesolithic}

The earliest evidence for the systematic, complex and precisely orchestrated exploitation of aquatic resources dates to the 11th millennium BP, at the end of an era of rapid environmental changes and the beginning of the Holocene. This period is conventionally called the Mesolithic. It is the era of the opening of the Black Sea to the Aegean Sea, which along with the increased flow of the large rivers in Northern Greece led to increased productivity of the Aegean Sea [6-8]. Culturally the Aegean shores were sparsely populated by communities of hunters, gatherers, and fishermen $[9,10]$. There is unequivocal evidence that Mesolithic people, were able to cross considerable distances between the mainland and the Aegean islands of the time $[11,12]$. Three archaeological sites, two caves (Franchthi
Cave in Argolid [13] and the Cave of Cyclops at Yioura in Sporades [14,15]) and the open air site of Maroulas on Kythnos [16] provide ample evidence for fishing during the early Holocene. Excavation at these sites produced thousands of fish bones and scales, as well as a large number of sea shells, marine mammal bones and sea bird bones. The ensuing discussion is based on data from a number of sites [17-29].

The fish present at these sites were mostly inshore species of medium size $(20-40 \mathrm{~cm})$. Groupers (Epinephelus sp.), scorpion fishes (Scorpaenidae), wrasses (Labridae) and also the John dory (Zeus faber), common dentex (Dentex dentex), common pandora (Pagellus erythrinus), white sea bream (Diplodus sargus) and other members of the Sparidae were the most common. The excavation in the Cave of Cyclops at Yioura revealed a part of the Mesolithic fishing technology that targeted these fish species, in the form of fishing hooks [30]. They are made of bone and antler and they come in two shapes, the bi-pointed gorges and the classic curved shape that survives to date (Figure 1). A second category of fish found in these sites are the euryaline species, with mullets (Mugilidae) being the most common. Their catch in considerable numbers can be taken as an indication for the presence of coastal brackish environments. This can only be verified for Franchthi, where special studies on the coastal morphology through time have been performed [20,31]. What is particularly interesting, however, is the fact that even at Franchti, Mugilidae were never very common, or at least not as common as another gregarious type of fish, the migratory Scombridae.

Remains of migratory fish are fairly common in all three Mesolithic sites mentioned above (Figure 2). Even though large tunas (Thunnus sp.) were regularly caught

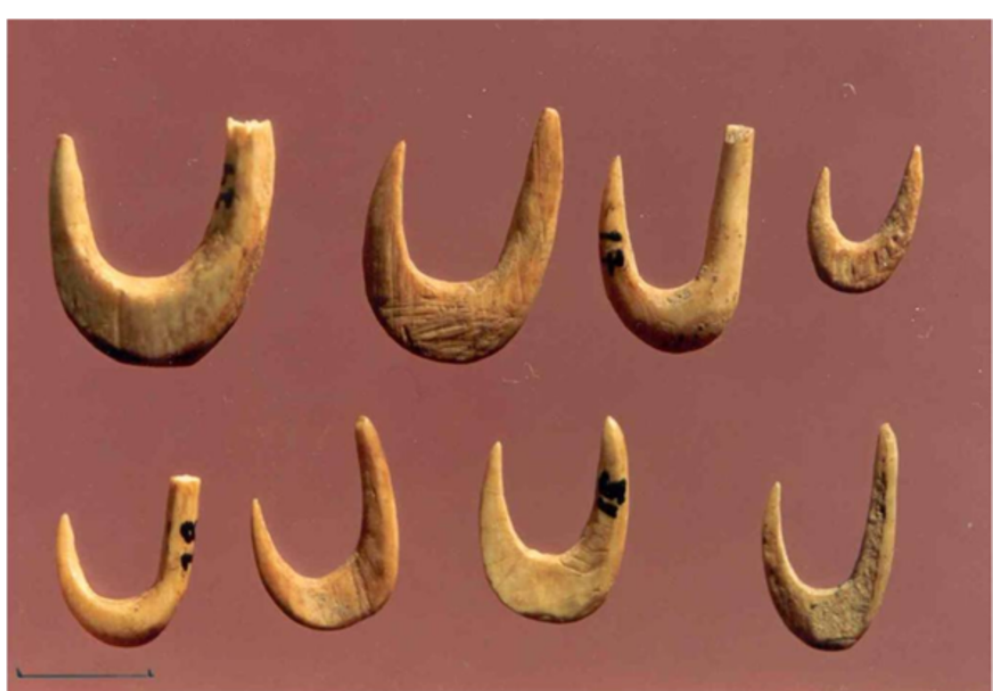

Figure 1 Cave of Cyclope, Youra. Bone fish hooks (A. Sampson). 


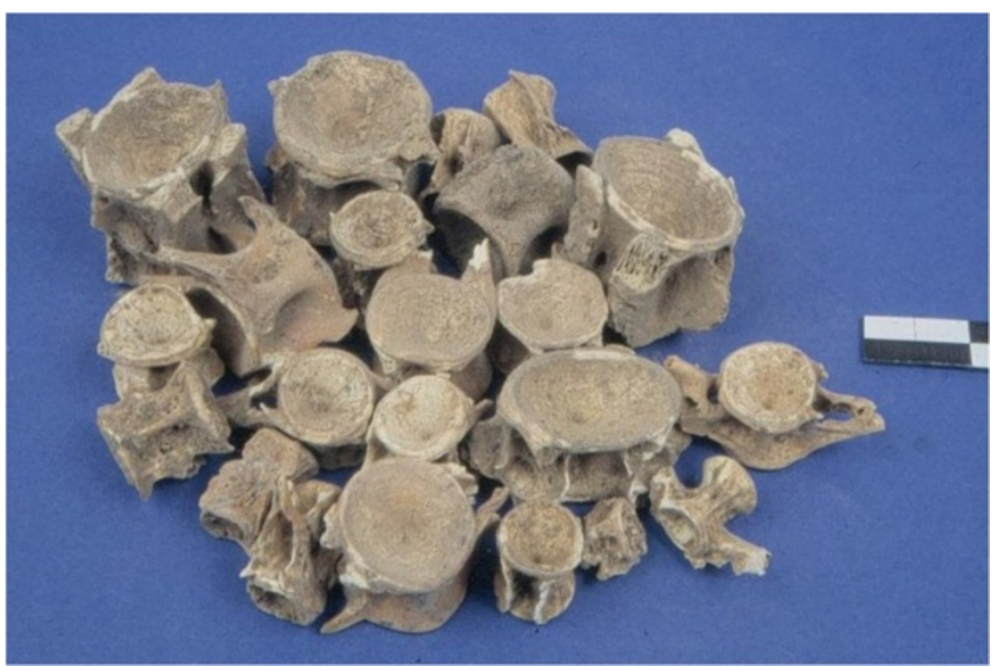

Figure 2 Cave of Cyclope, Youra. Thunnus sp. and Mugilidae spp. vertebrae (A. Sampson).

and consumed, with a preference towards small or medium pelagic individuals, fishermen mostly targeted the smaller species within the family (e.g. Scomber japonicus, Euthynnus alletteratus, Sarda sarda and Auxis rochei). This selectivity towards smaller sizes might be related to the ease by which smaller fish could be handled, as opposed to larger and heavier individuals.

In the Mesolithic, the first evidence for fish processing was found. In the osteological assemblage from the Cave of Cyclops on Yioura, certain anatomical parts of some migratory fish, such as the first vertebrae and the cranial bones of little tunnies (Euthynnus alletteratus), are systematically under-represented or missing altogether. This fact suggests that these elements had been removed before the fish were brought in the cave. Traditionally, the removal of the head and innards is the first step in the process of fish preservation, especially for blood-rich fish such as the Scombridae. An interest in fish processing is also vividly illustrated in the open air settlement at Maroulas on Kythnos. At this site, the whole fish had been stored in the floors of the circular huts (Figure 3). As in Yioura, in some cases, the head bones and the first vertebrae were absent. No information on fish processing has been reported from Franchthi cave so far, but this is probably only because the analysis and subsequent publication of the results on fish remains from this cave is still ongoing. Evidence from other Mesolithic sites on Cyprus [32] but also in Southern Italy [33] suggest that already at that time a common fish preservation tradition had been developed in Central and Eastern Mediterranean.

\section{Fishing in lakes, rivers, and the sea in the Neolithic}

The Mesolithic fishing bonanza, when marine aquatic resources were abundant and intensively exploited in coastal and near-coastal sites did not seem to continue in the following millennia. From the Neolithic period, between the 7 th and the 4th millenium BC, after the adoption of agriculture and animal husbandry as the main economic modes throughout the Hellenic peninsula [34-37], the exploitation of aquatic resources, mostly the marine ones, diminishes. The contribution of fish and aquatic molluscs to the Neolithic diet never superseded that of the domestic animals (i.e. the cattle, the pig and the ovicaprids).

At certain locations, however, especially in eutrophic areas, fishing and shell gathering remained an important activity, and some of the technological knowledge of the Mesolithic survived. The Neolithic lake-side settlement at Dispilio, on the south coast of the Lake Orestias near Kastoria, is one such example. To judge by their quantity, fish and mollusks were procured regularly and in considerable amounts and bone and antler fish hooks were also very common [38-41]. In the area of Amphipolis, near the estuaries of Strymon River in northern Greece, Neolithic people were making use of all three ecosystems, the river, the estuaries, and the sea. As a result, the remains of fish from all these habitats were found with emphasis, however, to those from the river and its estuaries. Various species of the Mugilidae family are particularly common at Kryoneri as are the various river fish such as the European perch (Perca fluviatis), the Northern pike (Esox lucius), the tench (Tinca tinca), and the common carp (Cyprinus carpio) and especially the eel (Anguilla anguilla) and the large cat-fish (Silurus glanis) (Figure 4), both of which acquired a fame of excellence in later Classical Greece [42]. Fishing and shellfish gathering was equally intensive in several other riverside or lakeside settlements in northern Greece, e.g. along the route of Aliakmon river or on the shores of now-dried up lakes such as the Giannista lake [43], 


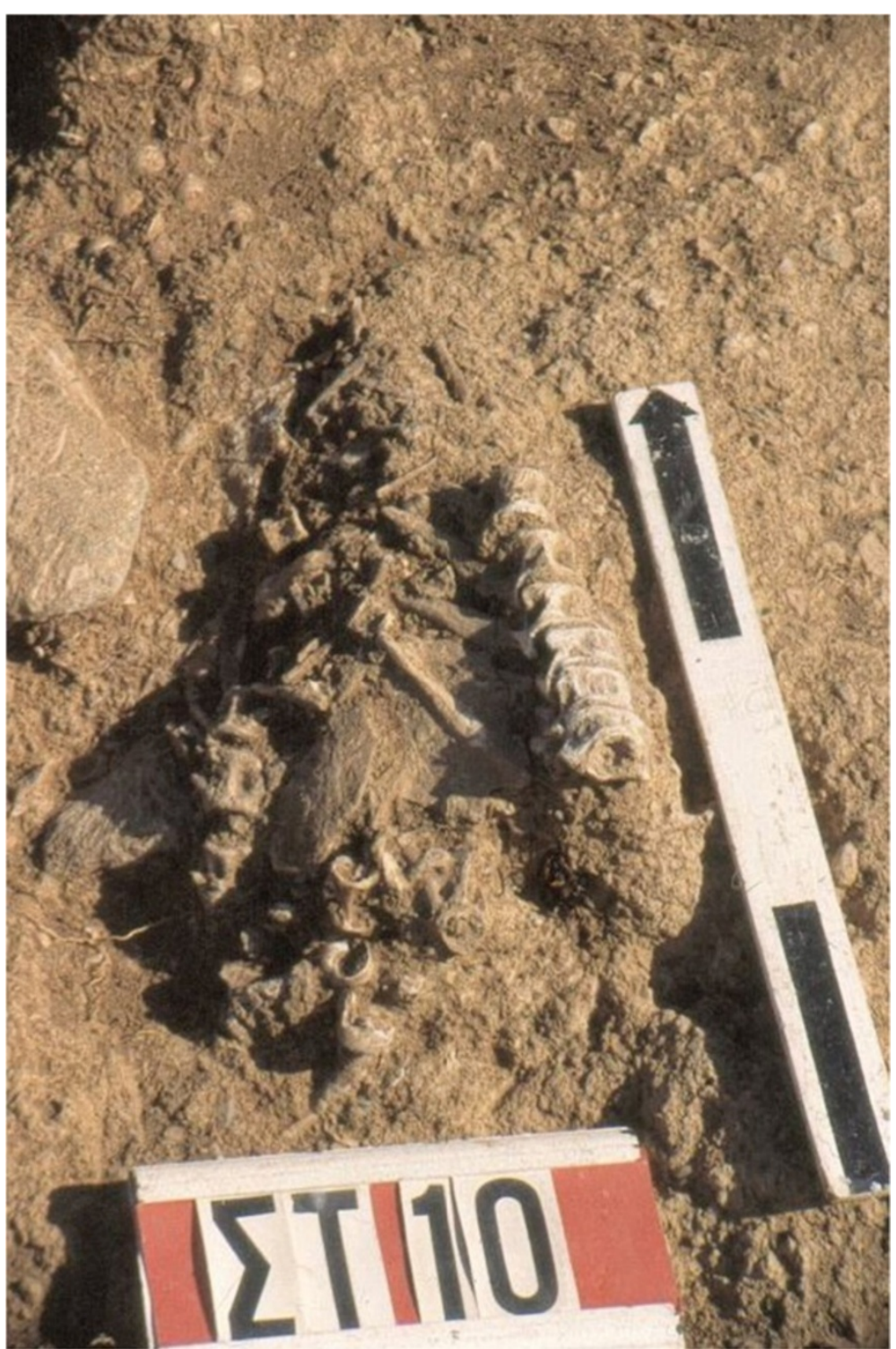

Figure 3 Maroulas, Kythnos. Two fish skeletons found in the floor of a circular hut (A. Sampson).

but also at some coastal and insular locations, such as Agios Petros in Sporades [44] or Makrygialos on the coast of Pieria [45] and others [46]. In the Neolithic era we have robust evidence that shellfish gathering was not only diet-related but served other purposes as well. Spondylus shells, for example, that were gathered in the Aegean Sea, were modified into ring-shaped ornaments and, through a complex exchange network, they travelled to Central Europe [47-49].

\section{Bronze Age exploitation of the aquatic resources as a} multi-level act

In the Bronze Age (3rd and 2nd millennium BC), our understanding of fishing and fishing products increases exponentially. The picture drawn by archaeology is both complex and detailed. The character of fishing in the Aegean Sea, as far as the exploited species and the relevant fishing technology is concerned, was consolidated. Aquatic, mainly marine, organisms were systematically processed on a large scale not only for food but also for the production of luxury products. Marine elements, physical and manmade such as octopus, fish, shellfish of various kinds, marine vegetation, and rocks, as well as ship of various types, naturalistic or more schematic, became popular decorative motifs in art [50,51] (Figure 5). More clearly than before, in this period, the sea and the aquatic animals participated in the social and religious ritual [52].

In the Bronze Age most of the consumed fish throughout the Aegean Sea were inshore fish of the shallow or 


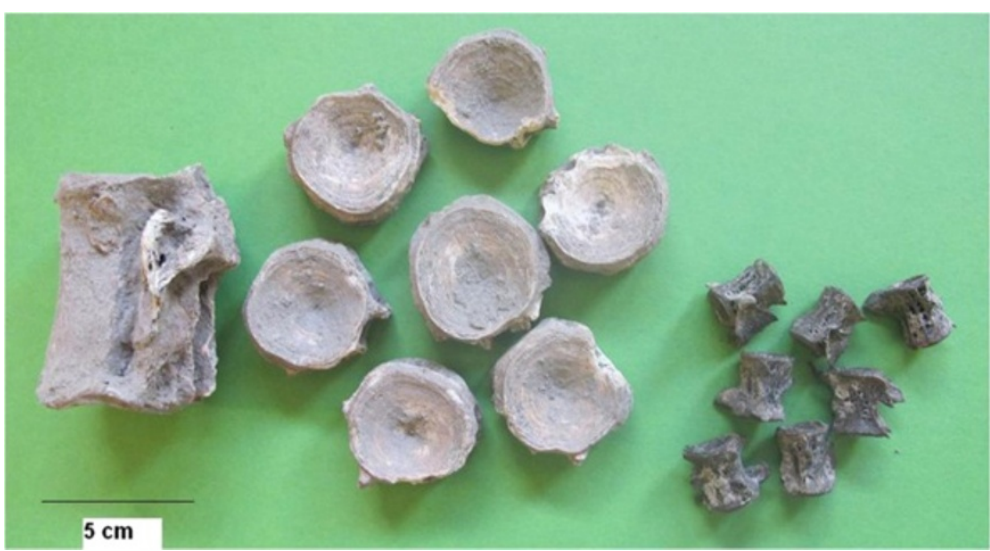

Figure 4 Kryoneri, Serres. Fish bones of Silurus glanis and Mugilidae spp. (D. Mylona).

even very shallow waters (Figure 6). The following discussion is based on data from various sites: Palaikastro [53], Mochlos [54,55], Pseira [54,56], Kommos [54,57]. In southern Aegean Sea, the picarels (Centracanthidae) and the bogues (Boops boops), were most commonly caught species, while the annular sea bream (Diplodus annularis), the comber (Serranus cabrilla), the damsel fish (Chromis chromis), the small individuals of common pandora (Pagellus erythrinus), and the parrot fish (Sparisoma cretense) followed. But even larger size fish, such as the red porgy (Pagrus pagrus), the scorpion fish (Scorpaenidae), the leer fish (Lichia amia), the European barracuda (Sphyraena sphyraena), the stingray (Dasyatis sp.), and the sharks are fairly common. In other words, at least in the southern Aegean Sea, fishing was done in the shallows, very near the coast.

The migratory fish, which seasonally approach the coast and are traditionally caught by stationary traps that are linked to the coast [4], are less often caught in the southern Aegean than in the north. They are not altogether an untapped resource however. The wall paintings of the "Little Fisherman" at Akrotiri, vividly illustrate the capture of dolphin fish (Corypahena hypurus) and of little tunnies (Euthynus aleteratus) or bullet tunnies (Auxis rochei) [58,59]. At the same site, a second piece of evidence suggests that the migratory fish were exploited even if not in large scale; this is the unique finding of two slices of tuna (Thunnus sp.) discovered in a frying pan. These were cooked in a makeshift kitchen, probably just hours before the catastrophic volcanic eruption occurred [60].

The fishing tools used in this period are adapted to the inshore fishing zone. Bronze hooks were widely used and we find them in all sizes and configurations, simple or complex, with a barb or without [3], some having a closed shape for the capture of bottom feeders and other having a more open shape for surface swimmers. Nets were also widely used, and we do find a variety of types, simple nets, trammel nets, and cast nets being the most common [3]. The nets are only rarely preserved archaeologically, due to the perishable nature of their fibers. Archaeological sites with good preservation, such as Akrotiri on Thera, provide such examples (Figure 7) [61]. What is usually preserved are the non-perishable, metal or stone elements of the nets, such as the lead folded sheets or the perforated pebbles, both of which functioned as weights $[3,62]$. There is even some evidence, that in the Bronze Age, baited baskets and the stationary fish traps, which at later periods are known as thynneia, were in use.

The gathering of edible shellfish and crustaceans follows the same motif (Figure 8). The top shells (Monodonta sp.), the limpets (Patella sp.) and the crabs were apparently consumed systematically, and at places in very large quantities. The ensuing discussion is based on data from the following sites: Palaikastro [63], Papadiokambos [64], unpublished observations, Mochlos [65], Pseira [66-68], and Kommos [69-71]. These animals are found in the

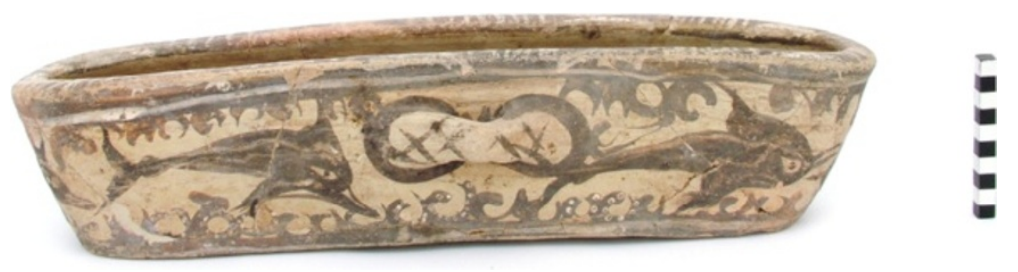

Figure 5 Akrotiri, Thera. Open vessel decorated with dolphins and marine vegetation (Akrotiri Excavations Archive). 


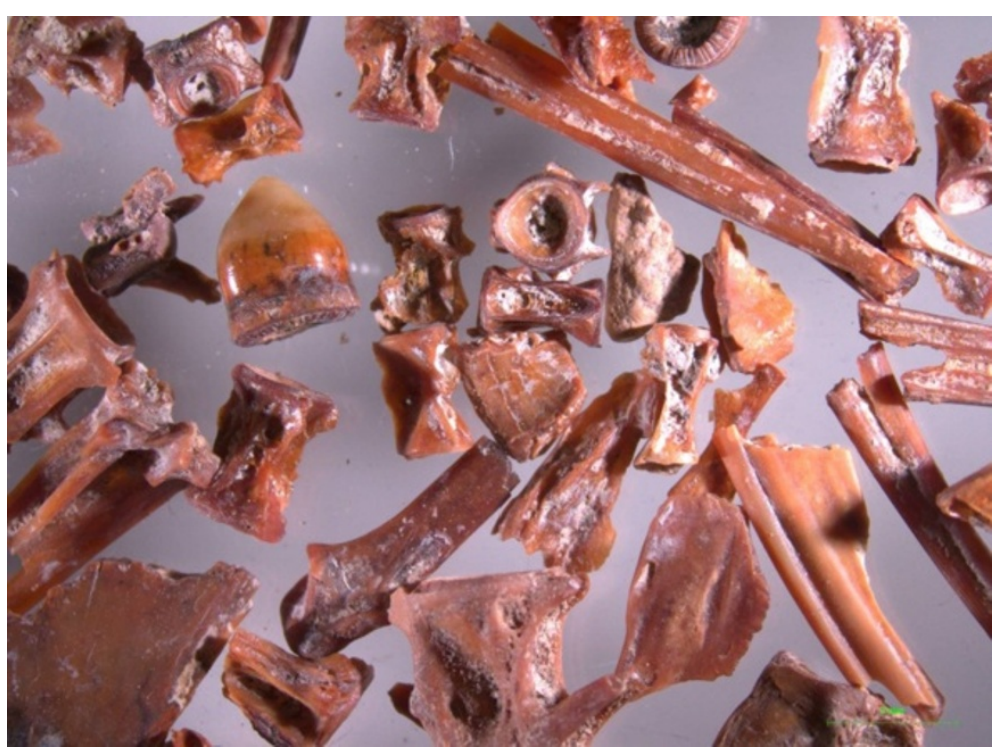

Figure 6 Akrotiri, Thera. Fish bones of small inshore fish (Akrotiri Excavations Archive).

mediolittoral zone, and can be gathered with hardly any technological investment and even minimal dexterity. This pattern is also broadly applicable in northern Greece, despite the fact that rich molluscan resources from different habitats, such as river estuaries and coastal lagoons were available and were exploited to some degree [46].

Shellfish gathering for special purposes other than the culinary was fairly different. It targeted species of deeper waters and it required diving skills and/or specialised technology both for the capture and processing of these animals. The fan mussel (Pinna nobilis), the purple shellfish (Muricidae) and the tritons (Charonia sp.) are some such species. The fun mussels were used for the production of decorative iridescent inlays [72]. The tritons were used modified or in their natural state as vessels for transferring liquids, as ceremonial vessels and as musical instruments (Figure 9) [73]. Large quantities of purple shellfish were

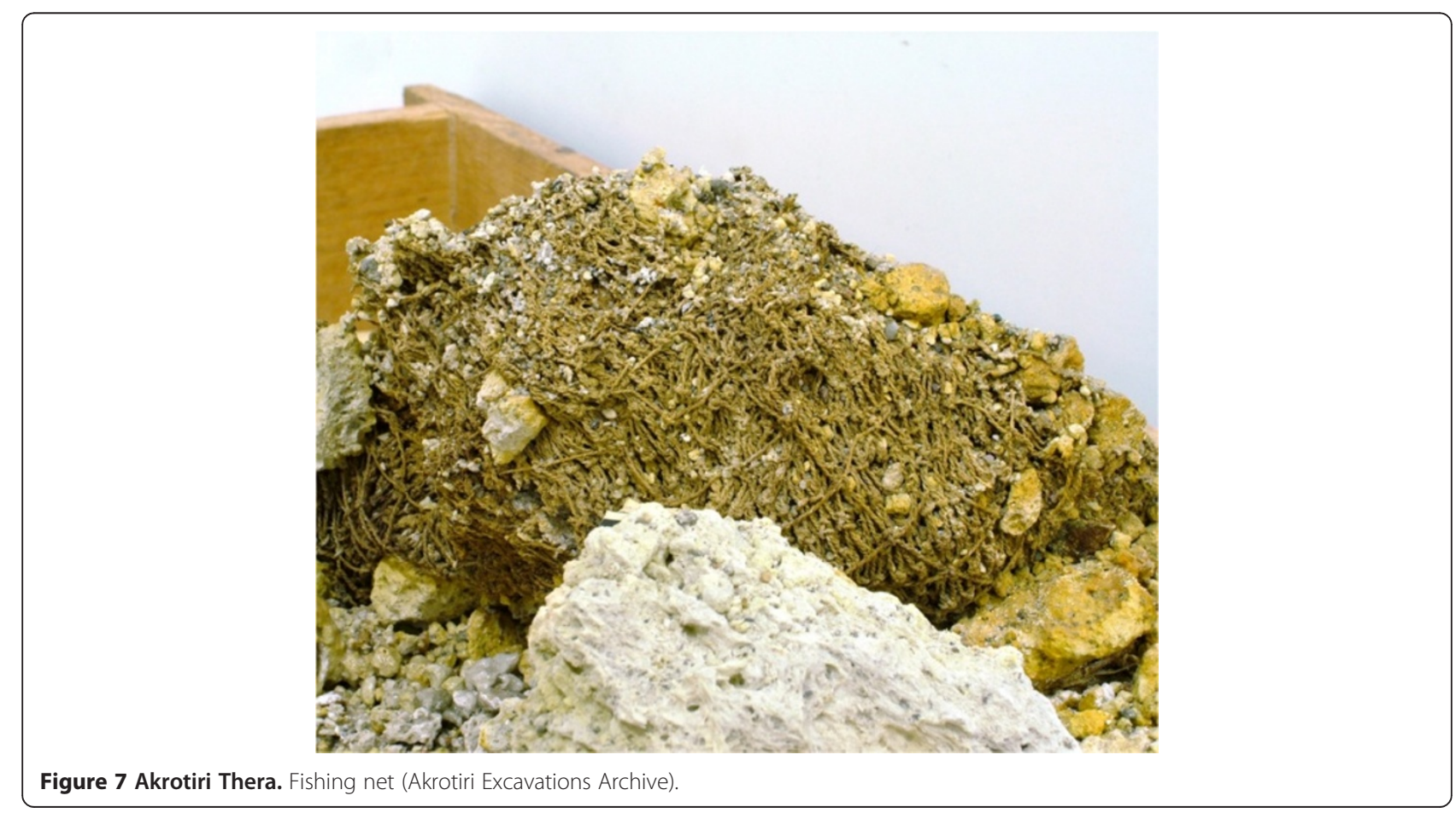




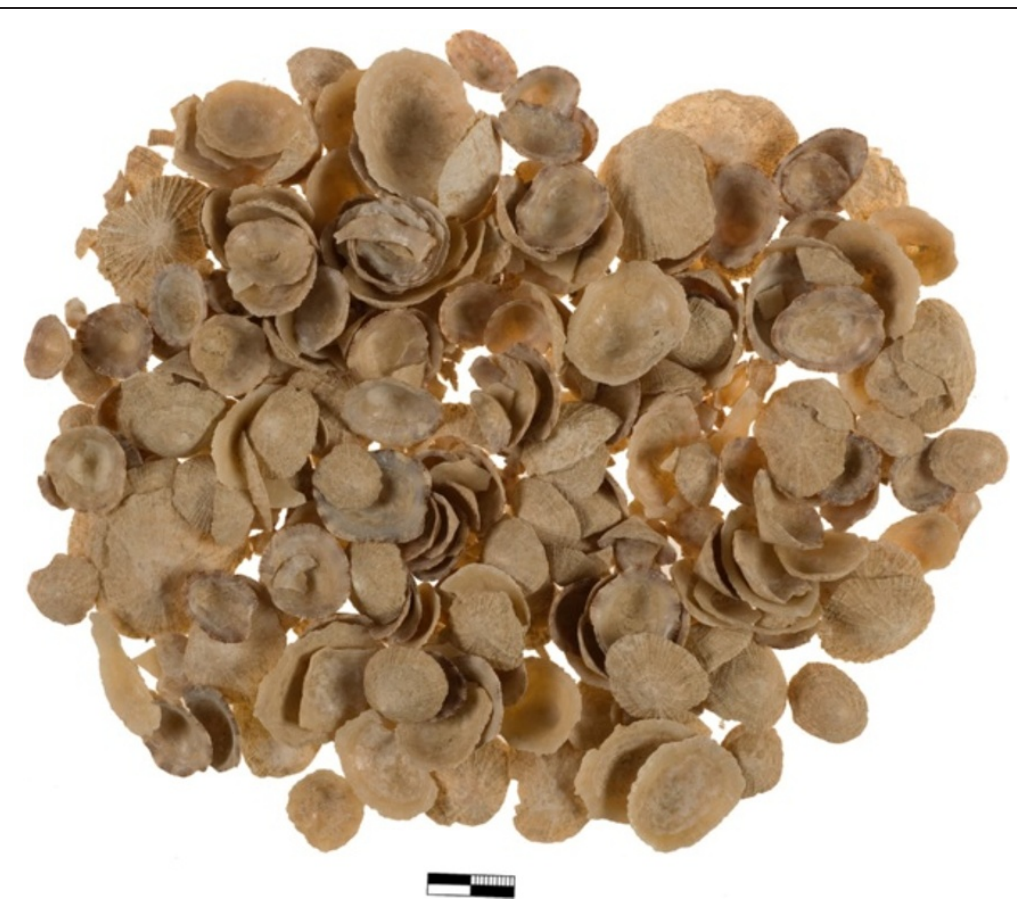

Figure 8 Papadiokambos, Siteia. Limpet shells (Patella sp.) (Ch. Papanikolopoulos - Papadiokambos Excavations Archive).

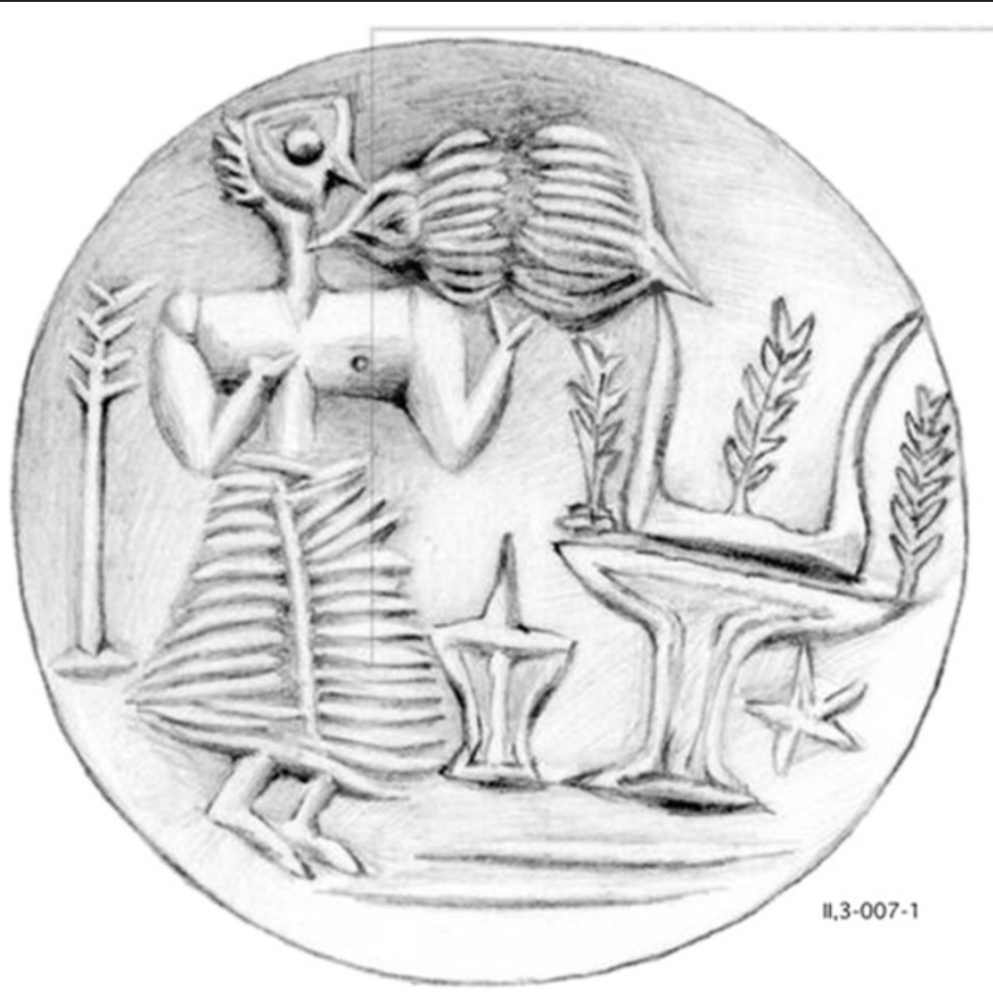

Figure 9 Idaeon Andron, Rethymno. Ritual scene with a triton (Charonia sp.) shell in use (CMS-II, 3-007-1). 


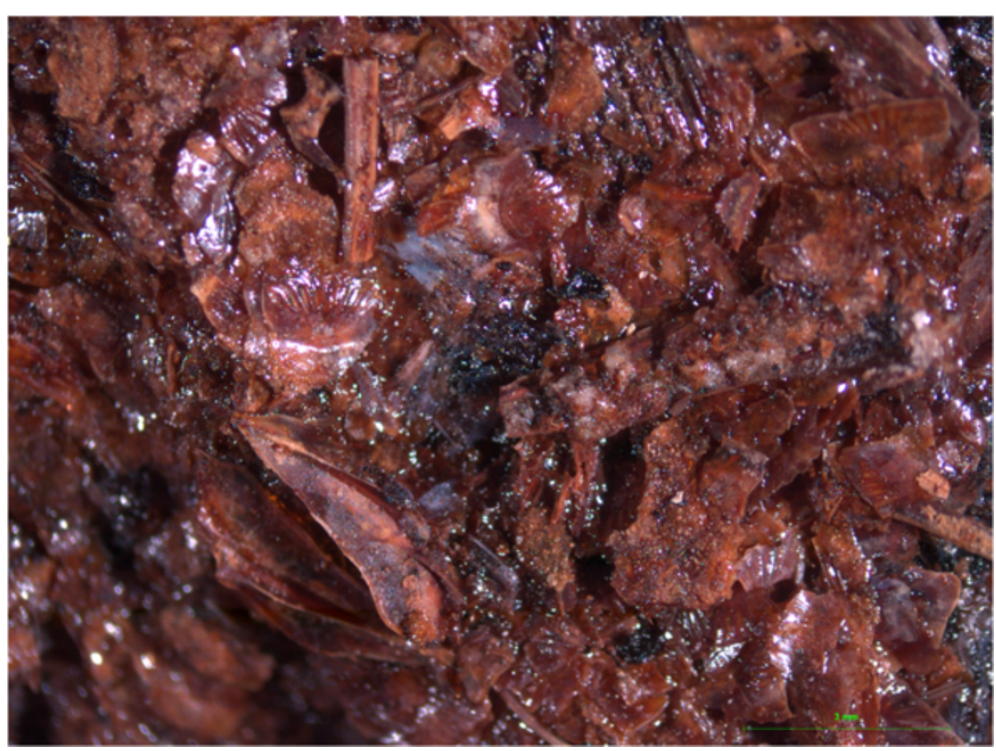

Figure 10 Akrotiri, Thera. Detail of the fish paste some fish bones can be discerned (D. Mylona).

used for the systematic production of purple dye on an industrial scale, from as early as $1800 \mathrm{BC}$ [74].

Similarly, special, articulated technologies developed around fish processing. The best examples for this were revealed by the excavations at the Bronze Age site of Akrotiri on Thera [75]. A massive volcanic eruption at around $1650 \mathrm{BC}$ covered the affluent, urban settlement of Akrotiri with a thick layer of volcanic ash. This material preserved the remains of the town in pristine condition. As a result, the archaeological excavations reveal a wide range of organic remains, which elsewhere would have disintegrated over time. Recent excavations revealed not only the fragile fishing net mentioned earlier but also another unique finding: a small storage vessel contained the desiccated remains of what appears to be a fish paste (Figure 10). This was made using various

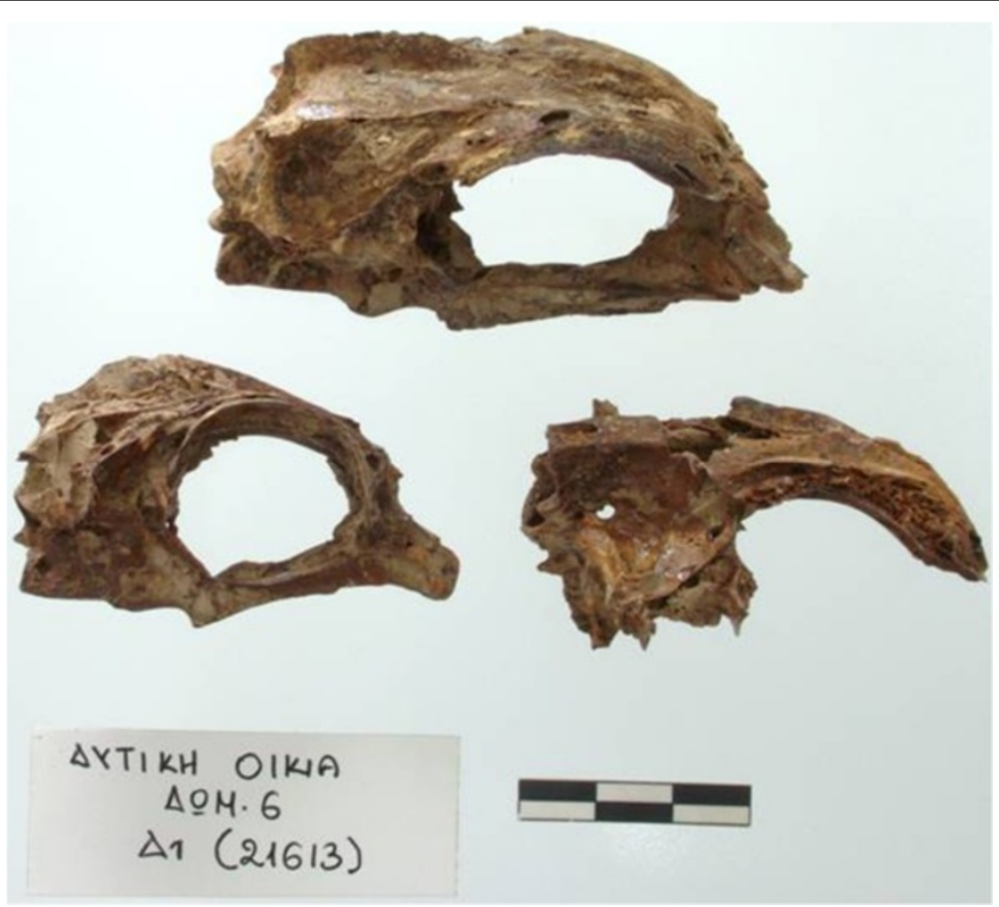

Figure 11 Akrotiri, Thera. Articulated crania of Pagrus pagrus found in a pithos (Akrotiri Excavations Archive). 
small fish such as picarels or bogues and small sting rays, seeds of an unidentified type of cereal and possibly other condiments, which have not been identified yet. This type of preserved fish product was known in more recent times, in the Roman world, as alec and was produced by fermentation of small fish and the innards of larger ones with the addition of salt, vinegar and other ingredients [76].

At the same location the excavators found the remains of several large-sized common dentex (Dentex dentex) individuals. The retrieved remains were articulated, and even a whole preserved fish, bones and flesh, was found. It is interesting that among these fish bones only the first and the last vertebrae were present, while the rest were missing altogether. It appears that the fish had been opened along their length, their vertebral column removed and the fish were probably salted and/or dried and hung on a string. Akrotiri provided another example of a different fish product, which was found in the ground floor store room of the so called "West House", the building which was decorated with the wall-paintings of the "Little Fisherman" mentioned earlier. A storage vessel contained the remains of a large number of red porgy (Pagrus pagrus) of similar size (Figure 11) and several seeds of an unidentified type of cereal. It appears that whole fish had been preserved in this vessel, making up the third identified type of a fish processing product at Akrotiri.

The special uses and the technologies involved in the exploitation of the marine molluscs and the elaborate processing of fish in the Bronze Age placed the sea and its creatures into spheres other than the dietary and the technological. These are the spheres of social competition and ideology.

\section{Conclusions}

The research on the exploitation of aquatic resources in antiquity was vastly enriched in the last decades by the collaboration of archaeology with biology and ecology. This rendered the physical remains of aquatic organisms, such as fish bones, sea shells, etc., eloquent testimonies of past fishing practices. Recent scientific developments open up more possibilities for collaboration between the archaeology of aquatic resources and the natural sciences. Molecular genetic analyses for identifying the remains of aquatic animals or their by-products e.g. $[77,78]$ and isotopic analysis e.g. [48] for exploring issues of provenance, diet, etc., are two such examples.

The exploration of the character of fishing and fishing products in the distant past reveals a picture which is both familiar and exotic. The sea, its organisms, the fishing tools and methods, the processing and consumption of aquatic foods are all very similar to what is known from Greece of the previous decades. The societies involved in fishing and consuming its products, however, were different on many aspects. A plethora of evidence suggests that the meanings given to these familiar activities were also different in those societies. Today, in this era of globalization, the relationship between the "common" and "familiar" on the one hand and the "different" and "strange" on the other, as these emerge from the study of fishing in the past, is particularly relevant.

\section{Competing interests}

The author declare that she has no competing interests.

\section{Authors' information}

DM is an archaeologist, who specializes in zoo-archaeology, with special emphasis in the analysis of remains of aquatic animals. She got her doctoral degree in Archaeology, University of Southampton (UK), and she wrote a thesis entitled "Fish-eating in Greece from the fifth century BC to the seventh century AD: a story of impoverished fisherman or luxurious fish banquets?". Her research focuses on various aspects of maritime communities that lived around the Aegean and the Mediterranean Sea in the past. DM is currently holding a post-doctoral position at the Institute of Aegean Prehistory, Crete, analyzing assemblages of animal remains from archaeological sites that range in date from Mesolithic to Byzantine.

\section{Acknowledgements}

This paper was first conceived as a presentation for the 15th Pan-Hellenic Congress of Ichthyologists "Aquatic ecosystems: uses, impacts and management", Thessaloniki, 10-13th of September 2013". I would like to thank Prof. Dr. T.J. Abatzopoulos for encouraging its publication in expanded form in this journal. I would also like to thank Dr. Tania Devetzi and Prof. A. Sampson for their help accessing the illustrations from Akrotiri, Cave of Cyclops and Maroulas and Emeritus Professors P. Economides and N. Galanidou for their constructive comments on earlier drafts of this paper. The comments of two anonymous reviewers are greatly appreciated.

Received: 9 December 2013 Accepted: 9 January 2014

Published: 13 May 2014

\section{References}

1. Wheeler A, Jones AKG: Fishes (Cambridge manuals in archaeology). Cambridge: Cambridge University Press; 1989.

2. Claassen C: Shells (Cambridge manuals in archaeology). Cambridge: Cambridge University Press; 1998.

3. Powell J: Fishing in the Prehistoric Aegean. Jonsered: Paul Åström; 1996

4. Mylona D: Eating Fish in Greece from 500 BC to AD 700. A story of impoverished fishermen or lavish fish banquets? Oxford: Archaeopress; 2008 [BAR International Series, vol.1754].

5. Mylona D: Fishermen, fish and fish bones: where archaeology meets Ichthyology. In Proceedings of the 10th Panhellenic Conference of Ichthyologists 2001, 10:313-316.

6. Kraft JC, Belknap DF, Kayan I: Potentials of discovery of human occupation sites on the continental shelves and nearshore coastal zones. In Quaternary Coastlines and Marine Archaeology: towards the prehistory of land bridges and continental shelves. Edited by Masters PM, Flemming NC. London: Academic Press; 1983:87-120.

7. Jones GA, Gagnon AR: Radiocarbon chronology of the Black Sea sediments. Deep-Sea Res 1994, 41:531-557.

8. Aksu AE, Hiscott RN, Mudie PJ, Rochon A, Kaminski MA, Abrajano T, Yasar D: Persistent Holocene outflow from the Black Sea to the Eastern Mediterranean contradicts Noah's Flood Hypothesis. GSA Today 2002, 12:4-10.

9. Galanidou N, Perlés C: The Greek Mesolithic. Problems and perspectives. London: Britisch School at Athens; 2003 [BSA Studies, vol. 10].

10. Galanidou N: Mesolithic cave use in Greece and the mosaic of human communities. J Medit Archaeology 2011, 24:219-242.

11. Renfrew $C$, Aspinall A: Aegean obsidian and Franchthi cave. In Les industries lithiques taillées de Franchthi (Argolide, Grèce). Les industries du Mésolithique et du Néolithique initial, Excavations at Franchthi Cave, fasc 5. Edited by Perlés C. Bloomington: Indiana University Press; 1990:257-270. 
12. Tzalas H: On the obsidian trail. With a papyrus craft in the Cyclades. In Trophis III. 3rd International Symposium on Ship Construction in Antiquity: 1989. Athens: Athens Hellenic Institute for the Preservation of Nautical Traditions; 1995:441-469.

13. Perlés C: The Mesolithic at Franchthi: an overview of the Data and Problems. In The Greek Mesolithic. Problems and perspective. Edited by Galanidou N, Perlés C. London: British School at Athens; 2003:79-88 [BSA Studies, vol. 10].

14. Sampson A: The Cave of the Cyclops: Mesolithic and Neolithic networks in the Northern Aegean, Greece. Vol. 1, intra-site analysis, local Industries, and regional site distribution. Philadelphia: INSTAP Academic Press; 2008 [Prehistory Monographs, vol. 21].

15. Sampson A: The Cave of the Cyclops: Mesolithic and Neolithic networks in the Northern Aegean, Greece. Vol. 11, bone tool industries, dietary resources and palaeo-environment, and archaeo-metrical studies. Philadelphia: INSTAP Academic Press; 2011 [Prehistory Monographs, vol. 31].

16. Sampson A, Kaczanowska M, Kozlowski JK: The Prehistory of the Island of Kythnos (Cyclades, Greece) and the Mesolithic Settlement at Maroulas. Kraków: The Polish Academy of Arts and Sciences - The University of Aegean; 2010.

17. Payne S: Faunal change at Franchthi Cave from 20,000 B.C. - 3000 B.C. In Archaeozoological Studies. Edited by Clason AT. Amsterdam: North-Holand Publishing; 1975:120-131

18. Payne S: Faunal evidence for environmental/climatic change at Franchthi Cave (Southern Argolid, Greece), 25,000 B.P. - 5000 B.P. Preliminary results. In Palaeo-climates, Palaeo-environments and Human Communities in the Eastern Mediterranean Region in Later Prehistory. Edited by Bintliff $J$, Van Zeist W. Oxford: Archaeopress; 1982:133-137 [BAR International Series 133].

19. Rose M: Fishing at Franchthi Cave, Greece: changing environments and patterns of exploitation. OWAN 1995, 18:21-26.

20. Shackleton JC, Van Andel T: Prehistoric shore environments, shellfish availability and shellfish gathering at Franchthi, Greece. Geoarchaeology 1986 1(2):127-143

21. Shackleton JC, Shackleton NJ, Deith MR: Marine Molluscan Remains from Franchthi Cave. Excavations at Franchthi Cave, fasc. 4. Bloomington: Indiana University Press; 1988.

22. Karali L: The seashells of Maroulas, Kythnos. In The Prehistory of the Island of Kythnos (Cyclades, Greece) and the Mesolithic Settlement at Maroulas. Edited by Sampson A, Kaczanowska M, Kozlowski JK. Kraków: The Polish Academy of Arts and Sciences - The University of Aegean; 2010:147-150.

23. Karali L: Malacological material. In The Cave of Cyclops. Mesolithic and Neolithic networks in the Northern Aegean, Greece, vol. II. Bone tool industry, dietary resources and the paleo-environmenal and archaeo-metrical studies. Edited by Sampson A. Philadelphia: INSTAP Academic Press; 2011:267-288 [Prehistory Monographs, vol. 31].

24. Powell J: Fishing in the Mesolithic and Neolithic - the Cave of Cyclops, Youra. In Zooarchaeology in Greece: Recent Advances. Edited by Kotjabopoulou E, Hamilakis Y, Halstead P, Gamble C, Elefanti P. London: British School at Athens; 2003:75-84 [BSA Studies, vol. 9].

25. Powell J: Non-Vertebral Fish Bones. In The Cave of the Cyclops: Mesolithic and Neolithic Networks in the Northern Aegean, Greece II: Bone Tool Industries, Dietary Resources and the Paleo-environment, and Archaeo-metrical Studies. Edited by Sampson A. Philadelphia: INSTAP Academic Press; 2011:151-236 [Prehistory Monographs, vol. 31].

26. Mylona D: Archaeological fish remains in Greece: general trends of the research and a gazetteer of sites. In Zooarchaeology in Greece: Recent Advances. Edited by Kotzabopoulou E, Hamilakis Y, Halstead P, Gamble C, Elefanti P. London: British School at Athens; 2003:193-200 [BSA Studies, vol. 9].

27. Mylona D: Mesolithic Fishers at Maroulas Kythnos. The fish bones. In The Prehistory of the Island of Kythnos (Cyclades, Greece) and the Mesolithic Settlement at Maroulas. Edited by Sampson A, Kaczanowska M, Kozlowski JK. Kraków: The Polish Academy of Arts and Sciences - The University of Aegean; 2010:151-162.

28. Mylona D: Fish vertebrae. In The Cave of Cyclops. Mesolithic and Neolithic networks in the Northern Aegean, Greece, vol. II. Bone tool industry, dietary resources and the paleo-environmenal and archaeo-metrical studies. Edited by Sampson A. Philadelphia: INSTAP Academic Press; 2011:237-268 [Prehistory Monographs, vol. 31]

29. Trantalidou K: From Mesolithic fishermen and bird hunters to Neolithic goat herders: the mammal and bird bone assemblages. In The Cave of the Cyclops: Mesolithic and Neolithic Networks in the Northern Aegean, Greece, vol. II. Bone tool industries, dietary resources and the paleo-environment, and archaeo-metrical studies. Edited by Sampson A. Philadelphia: INSTAP Academic Press; 2011:53-149 [Prehistory Monographs, vol. 31].

30. Moundrea-Agrafioti A: The Mesolithic and Neolithic bone implements. In The Cave of Cyclops. Mesolithic and Neolithic networks in the Northern Aegean, Greece, vol. II. Bone tool industry, dietary resources and the paleo-environmenal and archaeo-metrical studies. Edited by Sampson A. Philadelphia: INSTAP Academic Press; 2011:3-52 [Prehistory Monographs, vol. 31]

31. Thomas KD: Prehistoric coastal ecologies: a view from outside Franchth Cave, Greece. Geoarchaeology 1987, 2(3):231-240.

32. Desse J, Desse-Berset N: Strategies de peche au $8^{\mathrm{e}}$ millinnaire: les poissons de Cap Andreas-Kastros (Chypre). In Fouilles Recentes a Khirokitia (Chypre) 1988-1991. Edited by Le Brun A. Paris: Édition Reserches sur les Civilisations, ADPF; 1994:335-360.

33. Cassoli PF, Tagliacozzo A: Lo sfruttamento delle risorse marine tra il Mesolitico e il Neolitico alla Grotta dell'Uzzo, Trapani, (Sicilia). In Atti del $1^{\circ}$ Convegno nazionale di archeozoologia, Rovigo-Accademia dei Concordi, 5-7 marzo 1993. Rovigo: Centro polesano di studi storici, archeologici ed etnografici; 1995:157-169 [Padusa, vol. 1].

34. Demoule J-P, Perlès C: The Greek Neolithic: a new review. J World Prehist 1993, 7(4):355-416

35. Papathanasopoulos GA: Neolithic Culture in Greec. Athens: Museum of Cycladic Art; 1996.

36. Andreou S, Fotiadis M, Kotsakis K: Review of Aegean Prehistory V: The Neolithic and Bronze Age of Northern Greece. In Aegean Prehistory: A review. Edited by Cullen T. Boston: Archaeological Institute of America; 2001:259-327.

37. Perlès C: The Early Neolithic in Greece. The first farming communities in Europe. Cambridge: Cambridge University Press; 2001.

38. Albatzi K: Fishing in a lakeside settlement. In Dispilio. 7500 Years Later. Edited by Hourmouziadis GH. Thessaloniki: University Studio Press; 2002:135-144 [in Greek].

39. Theodoropoulou T: Man and lake: Fishers and fishing in Prehistoric Dispilio. Anaskamma 2008, 2:25-45 [in Greek].

40. Theodoropoulou T, Stratouli G: Fish bones vs. fishhooks: a comparative study from the Neolithic lakeside settlement of Dispilio, Greece. In Fishes-CultureEnvironment through Archaeoichthyology, Ethnography and History. Edited by Makowiecki D, Hamilton-Dyer S, Riddler I, Trzaska-Nartowski N, Makohonienko M Bogucki: Poznań; 2009:126-130 [Środowisko i kultura, vol. 7].

41. Veropoulidou R: Lake shellfish and terrestrial snails from the Neolithic Dispilio, Kastoria. Anaskama 2009, 3:13-26 [in Greek].

42. Mylona D: Animal bones from the Late Neolithic strata at Kryoneri, Serres: a preliminary report. AEMTH 2000, 11:523-538.

43. Theodoropoulou T: L'exploitation des faunes aquatiques en Égée septentrionale aux périodes pré- et Protohistoriques. Paris: Diss. Université de Sorbonne I, Panthéon- Sorbonne; 2007.

44. Schwartz C: Appendix II. Agios Petros: the vertebrate and molluscan fauna final report. In Agios Petros. A Neolithic site in the northern Sporades. Edited by Efstratiou N. Oxford: Archaeopress; 1985:151-160 [BAR International Series 241].

45. Pappa M, Halstead P, Kotsakis K, Bogaard A, Fraser R, Isaakidou V, Mainland I, Mylona D, Skourtopoulou K, Triantaphyllou S, Tsoraki C, Urem-Kotsou D, Valamoti S-M, Veropoulidou R: The Neolithic site of Makriyalos, Northern Greece: reconstruction of social and economic structure of the settlement through comparative study of the finds. In Subsistence, Economy and Society in the Greek World: improving the integration of archaeology and science. Edited by Voutsaki S, Valamoti SM. Leuven: Peeters; 2013:77-88.

46. Veropoulidou R: Molluscan Remains from Settlements along the Gulf of Thermaicos. Reconstructing shellfish consumption in the Neolithic and the Bronze Age. PhD Thesis. Thessalonike: University of Thessaloniki; 2011

47. Willms C: Neolithischer Spondylusschmuck. Hundert Jahre Forschung. Germania 1985, 63:331-343.

48. Ifantidis F, Nikolaidou M: Spondylus in Prehistory: New aata and approaches: Contributions to the Archaeology of Shell Technologies. Oxford: Archaeopress; 2011. BAR International Series 2216

49. Bajnóczi B, Schöll-Barna G, Kalicz N, Siklósi Z, Hourmouziadis G, Ifantidis F, Kyparissi-Apostoloka A, Pappa M, Veropoulidou R, Ziota C: Tracing the source of Late Neolithic Spondylus shell ornaments by stable isotope geochemistry and cathodoluminescence microscopy. J Archaeol Sci 2012, 40(2):874-882

50. Gill M: Some observations on representations of marine animals in Minoan art, and their identification. BCH 1985, 11(1):63-81.

51. Müller W: Kretische Tongefäße mit Meeresdekor. Entwicklung und Stellung innerhalb der feinen Keramik von Spätminoisch IB auf Kreta. Berlin: Gebr. Mann Verlag; 1997 
52. Vavouranakis G: The Seascape in Aegean Prehistory. Athens: Aarhus Universitetsforlag; 2011.

53. Mylona D: Fish remains from Well 576 and Well 605. In Palaikastro: Two Late Minoan Wells. Edited by Sackett H, MacGillivray A, Driessen J. Athens: The British School at Athens; 2007:217-220 [BSA Studies, vol. 43].

54. Rose JM: With Line and Glittering Bronze Hook: Fishing in the Aegean Bronze Age, Ph.D dissertation. Bloomington: Indiana University; 1994.

55. Mylona D: Fish remains. In Mochlos IC, Period III, Neopalatial Remains on the Coast: the Artisans' Quarter and the Chalinomouri Farmhouse. Edited by Soles J, Davaras C. Philadelphia: INSTAP Academic Press; 2004:121-125 [Prehistory Monographs, vol. 9].

56. Rose M: The fish bones. In Pseira I. The Minoan buildings on the west side of Area A. Edited by Betancourt PP, Davaras C, Banou E. Philadelphia: University Museum, University of Pennsylvania; 1998:145-148 [University Museum Monograph, vol. 90].

57. Reese DS, Rose MJ, Payne S: The Minoan fauna. In Kommos I. The Kommos region and houses of the Minoan town. Part 1. Edited by Shaw JW, Shaw MC. Princeton: Princeton University Press; 1995:163-290.

58. Economidis PS: The 'little fisherman' and the fish he holds. In International Symposium the Wall Paintings of Thera, Thera 30th August-4th September 1997. Edited by Sherrat S. London: Thera Foundation; 2000:555-562.

59. Mylona D: Representations of fish and fishermen on the Thera Wall Paintings in light of the fish bone evidence. In International Symposium the Wall Paintings of Thera, Thera 30th August-4th September 1997. Edited by Sherratt S. London: Thera Foundation; 2000:561-567.

60. Birtacha K, Devetzi A, Mylona D, Sarpaki A, Trantalidou K: The cooking installations in Late Cycladic IA Akrotiri on Thera: The case of the kitchen in Pillar Pit 65. Preliminary report. In 'Opí $\omega v$. A Colloquium on the prehistory of the Cyclades, Cambridge, 25th-28th March 2004. Edited by Brodie NJ, Doole J, Gavalas G, Renfrew C. Cambridge: McDonald Institute for Archaeological Research; 2008:349-375.

61. Moulherat C, Spantidaki Y, Tzachili I: Textiles, nets, strings and threads from Akrotiri Thera. Arachne 2004, 2:15-19 [in Greek].

62. Carter T: The stone implements. In Mochlos IC. Period III. Neopalatial Settlement on the Coast. The Artisan's Quarter and the Farmhouse at Chalinomouri. The Small Finds. Edited by Soles J, Davaras C. Philadelphia: INSTAP Academic Press; 2004:61-107 [Prehistory Monographs, vol. 9]

63. Reese DS: Palaikastro shells and Bronze Age purple-dye production in the Mediterranean Basin. BSA 1987, 201-206.

64. Brogan MT, Sofianou C, Morrison JE, Mylona D, Margariti E: Living off the fruits of the sea: new evidence for dining at Papadiokambos, Crete. In Subsistence, Economy and Society in the Greek World: improving the integration of archaeology and science. Edited by Voutsaki S, Valamoti SM. Leuven: Peeters; 2013:187-204.

65. Reese DS: The fauna. In Mochlos IC. Period III. Neopalatial settlement on the coast: The Artisans' Quarter and the farmhouse at Chalinomouri: The small finds. Edited by Soles JS, Davaras C. Philadelphia: INSTAP Academic Press; 2004:118-121 [Prehistory Monographs, vol. 9].

66. Reese DS: The faunal remains. In Pseira I. The Minoan Buildings on the west side of Area A. Edited by Betancourt P, Davaras C. Philadelphia: University Museum, University of Pennsylvania; 1995:11. 45-46, 56-57, 83 [University Museum Monograph 90].

67. Reese DS: The faunal remains. In Pseira III. The Plateia Buildings. Edited by Floyd RC, Betancourt PP, Davaras C. Philadelphia: University Museum, University of Pennsylvania; 1998:131-144 [University Museum Monograph 102]

68. Reese DA: faunal remains. In Pseira IV. Minoan Buildings in Areas B, C, C, and F. Edited by Betancourt PP, Davaras C. Philadelphia: INSTAP Academic Press; 1999:36-37. 80, 99, 136, 162-164, 184, 282-283 [University Museum Monograph 105]

69. Reese DS: The marine invertebrates. In Kommos I: The Kommos Region and Houses of the Minoan Town. Edited by Shaw JW, Shaw MC. Princeton: Princeton University Press; 1995:240-273.

70. Ruscillo D: Faunal remains and murex dye production. In Kommos V: The Monumental Minoan Buildings at Kommos. Edited by Shaw MC, Shaw JW. Princeton: Princeton University Press; 2006:776-844.

71. Ruscillo D: The faunal remains. In House $X$ at Kommos. A Minoan mansion near the sea. Part 1. Architecture, stratigraphy and selected finds. Edited by Shaw MC, Shaw JW. Philadelphia: INSTAP Academic Press; 2012:93-116 [Prehistory Monographs, vol. 35].

72. Karali L: Shells in Aegean Prehistory. Oxford: Archaeopress; 1999 [BAR International Series, vol. 761]
73. Apostolakou S, Betancourt PH, Brogan TH, Mylona D, Sofianou CH: Tritons Revisited. In PHYSIS. Natural environment and human interaction in the prehistoric Aegean. Paris: 14th International Aegean Conference; 2014, in press.

74. Brogan MT, Betancourt Ph P, Apostolakou V: The purple dye industry of Eastern Crete. In Kosmos. Jewellery, adornment and textiles in the Aegean Bronze Age. Proceedings of the 13th International Aegean Conference/13e Rencontre égéenne internationale, University of Copenhagen, Danish National Research Foundation's Centre for Textile Research, 21-26 April 2010. Edited by Nosch ML, Laffineur R. Leuven: Peeters; 2012:187-192.

75. Mylona D: Fish and seafood consumption in the Aegean: variations on a theme. In The Inland Seas: towards an ecohistory of the Mediterranean. Edited by Bekker-Nielsen T, Gertwagen R. Stuttgart: Franz Steiner Publishers; 2014, in press.

76. Curtis IR: Garum and Salsamenta. Production and commerce. Leiden: Studies in Medical History, Brill Academic Publications; 1991.

77. Dallongeville S, Garnier N, Casasola DB, Bonifay M, Rolando C, Tokarski C: Dealing with the identification of protein species in ancient amphorae. Anal Bioanal Chem 2011, 399(9):3053-3063.

78. Dallongeville S, Garnier N, Bernal Casasola D, Bonifa M, Rolando C, Tokarski C: Identification of Animal Species from Remains in Ancient Amphorae by Proteomics. In Hornos, Talleres y Focus de Produccion Alfarera en Hispania, vol. II. Edited by Bustamante JM, Dvaz JJ, Saez AM. Cádiz: Publicaciones de la Universidad de Cádiz; 2013:475-487.

doi:10.1186/2241-5793-21-2

Cite this article as: Mylona: Aquatic animal resources in Prehistoric Aegean, Greece. Journal of Biological Research-Thessaloniki 2014 21:2.

\section{Submit your next manuscript to BioMed Central and take full advantage of:}

- Convenient online submission

- Thorough peer review

- No space constraints or color figure charges

- Immediate publication on acceptance

- Inclusion in PubMed, CAS, Scopus and Google Scholar

- Research which is freely available for redistribution

Submit your manuscript at www.biomedcentral.com/submit
C) Biomed Central 